medRxiv preprint doi: https://doi.org/10.1101/2021.07.26.21260421; this version posted July 30, 2021. The copyright holder for this preprint (which was not certified by peer review) is the author/funder, who has granted medRxiv a license to display the preprint in perpetuity.

All rights reserved. No reuse allowed without permission.

\title{
Statistical Analysis Plan for the Helmet Non-Invasive Ventilation for COVID-19 Patients (Helmet-COVID) Randomized Controlled Trial
}

\author{
Yaseen Arabi, MD FCCP, FCCM, ATSF [YA] \\ Intensive Care Department, Ministry of National Guard Health Affairs \\ King Abdullah International Medical Research Center \\ King Saud Bin Abdulaziz University for Health Sciences, Riyadh, Saudi Arabia \\ yaseenarabi@yahoo.com
}

Haytham Tlayjeh, MD [HT]

Intensive Care Department, Ministry of National Guard Health Affairs

King Abdullah International Medical Research Center

King Saud Bin Abdulaziz University for Health Sciences, Riyadh, Saudi Arabia

tlayjehh@ngha.med.sa

\section{Sara Aldekhyl, MBBS [SD]}

College of Medicine, King Saud Bin Abdulaziz University for Health Sciences

King Abdullah International Medical Research Center

Ministry of National Guard Health Affairs, Riyadh, Saudi Arabia

DakheelS@NGHA.MED.SA

Hasan Al-Dorzi, MD [HD]

Intensive Care Department, Ministry of National Guard Health Affairs

King Abdullah International Medical Research Center

King Saud Bin Abdulaziz University for Health Sciences, Riyadh, Saudi Arabia

aldorzih@yahoo.com

\section{Sheryl Ann Abdukahil, RN [SA]}

Intensive Care Department, Ministry of National Guard Health Affairs

King Abdullah International Medical Research Center

King Saud Bin Abdulaziz University for Health Sciences, Riyadh, Saudi Arabia

abdukahil.sheryl@gmail.com

\section{Jesna Jose, PhD [JJ]}

Bioinformatics and Biostatistics Department, King Abdullah International Medical Research

Center

King Saud Bin Abdulaziz University for Health Sciences

Ministry of National Guard Health Affairs, Riyadh, Saudi Arabia

joseje@ngha.med.sa

Mohammad Khulaif Al Harbi, MD, FRCPC [MH]

Department of Anesthesia, Ministry of National Guard Health Affairs

King Abdullah International Medical Research Center

King Saud Bin Abdulaziz University for Health Sciences, Riyadh, Saudi Arabia

HarbiMK@NGHA.MED.SA

Husain Al Haji, RRT [HH]

Respiratory Services Department, Ministry of National Guard Health Affairs

King Abdullah International Medical Research Center

King Saud Bin Abdulaziz University for Health Sciences, Riyadh, Saudi Arabia

HajiH@NGHA.MED.SA 
medRxiv preprint doi: https://doi.org/10.1101/2021.07.26.21260421; this version posted July 30, 2021. The copyright holder for this preprint (which was not certified by peer review) is the author/funder, who has granted medRxiv a license to display the preprint in perpetuity.

All rights reserved. No reuse allowed without permission.

Mohammed Al Mutairi, RRT [MM]

Respiratory Services Department, Ministry of National Guard Health Affairs

King Abdullah International Medical Research Center

King Saud Bin Abdulaziz University for Health Sciences, Riyadh, Saudi Arabia

MutairyMM@NGHA.MED.SA

Omar Al Zumai, RRT [OZ]

Respiratory Services Department, Ministry of National Guard Health Affairs

King Abdullah International Medical Research Center

King Saud Bin Abdulaziz University for Health Sciences, Riyadh, Saudi Arabia

ZumaiO@NGHA.MED.SA

\title{
Eman Al Qasim, RN, MSN [EQ]
}

Research Office, King Abdullah International Medical Research Center

King Saud Bin Abdulaziz University for Health Sciences, Riyadh, Saudi Arabia Ministry of National Guard Health Affairs, Riyadh, Saudi Arabia

Eman77al-qasim@hotmail.com

Wedyan Al Wehaibi [WW]

Intensive Care Department, Ministry of National Guard Health Affairs

King Abdullah International Medical Research Center

King Saud Bin Abdulaziz University for Health Sciences, Riyadh, Saudi Arabia wedyan.mohammed@outlook.com

Saad Al Qahtani, MD, MMED, MAHA, FRCPC [SQ]

Intensive Care Department, Ministry of National Guard Health Affairs

King Abdullah International Medical Research Center

King Saud Bin Abdulaziz University for Health Sciences, Riyadh, Saudi Arabia mcmasterer@hotmail.com

Mohammed Alshahrani, MBBS, SSC-EM , ArEM, FCCM [MS]

Department of Emergency and Critical Care

King Fahad Hospital of the University

Imam Abdulrahman Bin Faisal University

Al Khobar, Kingdom of Saudi Arabia

msshahrani@iau.edu.sa

Talal Albrahim, MD [TI]

Department of Critical Care

King Fahad Hospital of the University

Imam Abdulrahman Bin Faisal University

Al Khobar, Kingdom of Saudi Arabia

talbrahim@iau.edu.sa

\author{
Ahmed Mady, MBBCH, MSc, MD,S-FCCM,FCCP [AM] \\ Intensive Care Department \\ King Saud Medical City \\ Riyadh, Saudi Arabia \\ College of Medicine \\ Tanta University, Egypt \\ afmady@hotmail.com
}

Ali Al Bshabshe, MD, SSCIM, JBIM, ArBIM, MRCP(UK), EDIC,CNSC [AB]

Department of Critical Care Medicine

King Khalid University, Aseer Central Hospital 
Abha, Kingdom of Saudi Arabia

albshabshe@yahoo.com

Zohair Al Aseri, MD, FCEM, FRCPC [ZA]

Emergency and Intensive Care Departments

College of Medicine

King Saud University

Riyadh, Saudi Arabia

zohairalaseri@yahoo.com

Zainab AI Duhailib, MBBS, EDIC, MSc [ZD]

Adult Critical Care Department

King Faisal Specialist Hospital \& Research Center

Riyadh, Saudi Arabia

zalduhailib65@kfshrc.edu.sa

Ayman Kharaba MD, ABIM,FRCPC [AK]

Pulmonary \& Critical Care Departments, King Fahad Hospital Madinah

Critical Care Units- Madinah Region, Ministry of Health

a7yman@hotmail.com

Rakan Alqahtani, MD [RQ]

Department of Critical Care, King Khalid University Hospital

King Saud University Medical City, Riyadh, Saudi Arabia.

arakan@KSU.EDU.SA

Haifa Algethamy, MD [HG]

Department of Anesthesia

King Abdulaziz University Hospital

Jeddah, Saudi Arabia

halgethamy2020@gmail.com

Omar Alfaris, RRT [OF]

Respiratory Services Department, Ministry of National Guard Health Affairs

King Abdullah International Medical Research Center

King Saud Bin Abdulaziz University for Health Sciences, Riyadh, Saudi Arabia

ALFARISOM@NGHA.MED.SA

\section{Omar Alnafel, MD}

Internal Medicine and Intensive Care Department

King Salman Specialist Hospital, Hail

dr.alnafal1@gmail.com

Abdulrahman A Al-Fares, MBChB, MRCP, ABIM, FRCPC [AF]

Department of Anesthesia, Critical Care Medicine and Pain Medicine

Al-Amiri Hospital, Ministry of Health, Kuwait

abdulrahman.alfares@gmail.com 
medRxiv preprint doi: https://doi.org/10.1101/2021.07.26.21260421; this version posted July 30, 2021. The copyright holder for this preprint (which was not certified by peer review) is the author/funder, who has granted medRxiv a license to display the preprint in perpetuity.

All rights reserved. No reuse allowed without permission.

\section{Corresponding author}

\section{Yaseen Arabi, MD FCCP, FCCM, ATSF [YA]}

(ORCID: 0000-0001-5735-6241)

Intensive Care Department, Ministry of National Guard Health Affairs, Riyadh, Saudi Arabia

King Abdullah International Medical Research Center

King Saud Bin Abdulaziz University for Health Sciences, Riyadh, Saudi Arabia

yaseenarabi@yahoo.com 


\section{Abstract}

\section{Background and objective}

Noninvasive respiratory support is frequently needed for patients with acute hypoxemic respiratory failure due to coronavirus disease 19 (COVID-19). Helmet noninvasive ventilation having multiple advantages over other support modalities but data about effectiveness are limited.

\section{Methods}

In this multicenter randomized trial of helmet non-invasive ventilation for COVID-19 patients (Helmet-COVID), 320 adult ICU patients with suspected or confirmed COVID-19 and acute hypoxemic respiratory failure (with a ratio of arterial oxygen partial pressure to fraction (percent) of inspired oxygen $\left(\mathrm{PaO}_{2} / \mathrm{FiO}_{2}\right)<200$ despite supplemental oxygen with a partial/non-rebreathing mask at a flow rate $>10 \mathrm{~L} / \mathrm{min}$ or above) will be randomized to helmet-noninvasive ventilation with usual care or usual care alone. The primary outcome is death from any cause within 28 days after randomization. The trial has $80 \%$ power to detect a $15 \%$ absolute risk reduction from $40 \%$ to $25 \%$.

\section{Conclusion}

Consistent with international guidelines, we developed a detailed plan to guide the analysis of the Helmet-COVID trial. This plan specifies the statistical methods for the evaluation of primary and secondary outcomes to facilitate unbiased analyses of clinical data.

Trial registration: Clinicaltrials.gov: NCT04477668 (registered on July 20, 2020) 
medRxiv preprint doi: https://doi.org/10.1101/2021.07.26.21260421; this version posted July 30, 2021. The copyright holder for this preprint

(which was not certified by peer review) is the author/funder, who has granted medRxiv a license to display the preprint in perpetuity.

All rights reserved. No reuse allowed without permission.

\section{Introduction}

Acute hypoxemic respiratory failure is a common feature of severe coronavirus disease 19 (COVID-19) and frequently requires respiratory support. As invasive mechanical ventilation carries high morbidity and mortality, other respiratory modalities, such as high-flow nasal oxygen and noninvasive ventilation (NIV) by face mask and helmet, have been suggested and increasingly practiced. Helmet NIV has multiple advantages over other modalities that may include more effective seal, less transmission of the virus, more effective delivery of positive end-expiratory pressure, and greater tolerance.(1) Helmet NIV has been investigated as a treatment in adult patients with acute hypoxic respiratory failure.(2-6) A network meta-analysis of 25 studies that included 3804 patients with acute hypoxemic respiratory failure for reasons other than COVID-19 found significant lower intubation (risk ratio, 0.26 ; $95 \%$ credible interval, $0.14-0.46$ ) and mortality (risk ratio, $0.40 ; 95 \%$ credible interval, 0.24-0.63) risks with helmet NIV compared with standard oxygen therapy.(7) The absence of high-quality evidence on helmet NIV in COVID-19 led to the design and conduct of randomized controlled trials (RCTs). Recently, an RCT compared the early application of 48 hours of helmet NIV or HFNO in 109 patients with moderate to severe hypoxemia (ratio of partial pressure of arterial oxygen to fraction of inspired oxygen $\left(\mathrm{PaO}_{2} / \mathrm{FiO}_{2}\right)$ ratio $\left.\leq 200\right)$ showed no difference in the number of days free of respiratory support at 28 days (primary outcome) with a significantly lower incidence of intubation and a higher number of invasive mechanical ventilation-free days at 28 days in the helmet NIV group.(8)

The helmet non-invasive ventilation for COVID-19 patients (Helmet-COVID) trial is a concealed, stratified, unblinded multicenter RCT that examines the effect of helmet NIV compared to usual care on 28-day mortality in patients with acute hypoxic respiratory failure due to COVID-19. The full trial protocol has been published previously.(9)

In this manuscript, we describe the statistical analysis plan (SAP) of the helmet COVID trial. This plan complies with the International Conference on Harmonisation of Technical 
medRxiv preprint doi: https://doi.org/10.1101/2021.07.26.21260421; this version posted July 30, 2021. The copyright holder for this preprint

(which was not certified by peer review) is the author/funder, who has granted medRxiv a license to display the preprint in perpetuity.

All rights reserved. No reuse allowed without permission.

Requirements for Registration of Pharmaceuticals for Human Use, and both the "Statistical principles for clinical trials E9" and "Structure and content of clinical study reports E3".(10,

11) The report describes the procedures for the primary and secondary analyses. All analyses were prospectively defined as the SAP was finalized during trial implementation. The SAP was written by the Principal Investigator and members of the Steering committee, who will remain blinded to the study results until all patients have been recruited and the database has been locked. Participant recruitment is expected to be complete in the summer of 2021. The final study report will follow the CONSORT (Consolidated Standards of Reporting Trials) 2010 guidelines for reporting RCTs.(12, 13)

\section{Methods}

\section{Study Design}

The Helmet-COVID trial will enroll 320 critically ill patients in Saudi Arabia and Kuwait. The study has been approved by the Institutional Review Boards of the participating sites. The trial is registered in clinicaltrials.gov (NCT04477668). The study is sponsored by King Abdullah International Medical Research Center (Protocol number RC20/306/R), Riyadh, Saudi Arabia. The sponsor has no role in the study design, management, or analysis.

\section{Study Population}

All adult (adult ICU cut-off age) patients admitted to the ICU with suspected or confirmed COVID-19 by reverse transcription-polymerase chain reaction (RT-PCR) will be screened for eligibility. Inclusion criteria include acute hypoxemic respiratory failure (the ratio of arterial oxygen partial pressure to fraction (percent) of inspired oxygen $\left(\mathrm{PaO}_{2} / \mathrm{FiO}_{2}\right.$ ratio $)<200$ despite supplemental oxygen with a partial/non-rebreathing mask at a flow rate $>10 \mathrm{~L} / \mathrm{min}$ or above) with intact airway protective gag reflex and able to follow instructions. Exclusion criteria include imminent intubation and requirement for more than one vasopressor. A full list of inclusion and exclusion criteria is described in the published protocol.(9) 
medRxiv preprint doi: https://doi.org/10.1101/2021.07.26.21260421; this version posted July 30, 2021. The copyright holder for this preprint

(which was not certified by peer review) is the author/funder, who has granted medRxiv a license to display the preprint in perpetuity.

All rights reserved. No reuse allowed without permission.

A flow diagram will be constructed according to the CONSORT guidelines (Figure 1). We will report the number of patients who were screened, met inclusion or exclusion criteria, were eligible but not enrolled with reasons for non-enrollment. We will report the number of patients who were randomized to each group, received the allocated intervention, and included in the final analysis.

The Intention-to-treat population consists of all enrolled patients and will be used for the primary analysis. All enrolled patients will be included regardless of whether they receive or do not receive the allocated intervention. All patients enrolled with suspected COVID-19 will remain in the study, even if they tested negative for COVID-19 after enrollment. Postenrollment exclusion from the intention-to-treat analysis will be restricted to the withdrawal of consent to use trial data by the patient or surrogate decision-maker (SDM) or wrong randomization. However, if the patient or SDM withdraws consent for trial participation but permits collection and use of data, we will include these participants in the planned intentionto-treat analysis. We plan to enroll additional patients to compensate for patients who are excluded post-randomization.

The per-protocol population consists of all randomized patients who received the allocated intervention (helmet NIV in the helmet NIV group, and no helmet NIV in the usual care group). Patients will be considered to have received helmet NIV if the device was applied for 1 hour or more.

Patient and public involvement

No patient involved 


\section{Analysis Plan}

\section{Baseline Characteristics}

We will present baseline characteristics in patients randomized to the helmet NIV and usual care of the intention-to-treat cohort (Supplement Table S1). We will report in the two groups patients age, sex, height, weight, body mass index, location before ICU admission (emergency room, hospital ward, other hospitals (ICU or ward), others), Acute Physiology and Chronic Health Evaluation (APACHE) II, sequential organ failure assessment (SOFA) score, comorbidities (any chronic comorbidity, chronic cardiac, pulmonary disease, renal, liver, and neurological diseases, diabetes, any malignancy including leukemia or lymphoma and metastatic solid tumor, AIDS/HIV, rheumatologic diseases, others). Because we are enrolling patients with confirmed or suspected SARS-CoV-2 infection, we will report whether the patient is eventually confirmed to have SARS-CoV-2 infection. We will report physiologic parameters before randomization (partial pressure of oxygen $\left(\mathrm{PaO}_{2}\right)$, fraction of inspired oxygen $\left(\mathrm{FiO}_{2}\right), \mathrm{PaO}_{2} / \mathrm{FiO}_{2}$ ratio, partial pressure of carbon dioxide $\left(\mathrm{PaCO}_{2}\right)$, and $\left.\mathrm{pH}\right)$ and the number of quadrants with infiltrates on the chest radiograph. We will report respiratory support at baseline (high-flow nasal cannula, mask noninvasive ventilation, other oxygen devices). We will document respiratory rate and whether the patient is treated with awake prone positioning. We will document the number of days from onset of symptoms to the emergency room and ICU admission, and the number of days from ICU admission to randomization. We will report organ support, including vasopressor therapy and renal replacement therapy.

\section{Intervention Data}

For each day in the first 96 hours, we will report in each group the details regarding helmet NIV (number of hours used, highest pressure support level, and PEEP). Throughout the first 28 days, we will document the number of days received helmet ( $>1$ hour) and the total hours of helmet NIV. Non-tolerance to helmet NIV is defined as not using helmet NIV for at least 1 
hour. We will document the reasons for discontinuation of the helmet NIV (clinical improvement, the patient required intubation, helmet intolerance with use of $<1$ hour or $>1$ hour, helmet removal due to change in goals of care, death while on helmet). We will document respiratory support post helmet NIV (mask NIV, high-flow nasal oxygen, other oxygen devices, intubation). Violations to the study protocol will be documented including the use of NIV helmet in the usual group, and lack of attempt to use helmet NIV in the intervention group (Supplement Table S2).

\section{Co-Interventions:}

In both groups, we will document the use of other respiratory support modalities during the first 4 days (mask NIV with highest pressure support and PEEP, high-flow nasal cannula with flow rate, other oxygen devices, awake prone position), arterial blood gases, and fluid intake and output (Supplement Table S2).

\section{Physiologic variables during the intervention}

For the 28 days, we will document modalities of respiratory support, the use of sedation while not intubated (dexmedetomidine), renal replacement therapy, and vasopressors/Inotrope therapy. We will document the use of COVID-19 interventions, including corticosteroids, IL-6 receptor antagonists, and antiviral therapy. We will document serial $\mathrm{PaO}_{2} / \mathrm{FiO}_{2}$ ratio, $\mathrm{PaCO}$, fluid balance, and serial SOFA scores (Supplement Table S2).

\section{Primary Outcome}

The primary outcome is all-cause 28-day mortality. The primary outcome tests the primary hypothesis that helmet NIV reduces 28-day mortality (Supplement Table S3).

\section{Secondary outcomes}


medRxiv preprint doi: https://doi.org/10.1101/2021.07.26.21260421; this version posted July 30, 2021. The copyright holder for this preprint (which was not certified by peer review) is the author/funder, who has granted medRxiv a license to display the preprint in perpetuity.

All rights reserved. No reuse allowed without permission.

A detailed list of secondary outcomes with definitions has already been published and is outlined in Supplement Table S4. These secondary outcomes can be grouped as follows:

1. Mortality outcomes
a. ICU mortality
b. Hospital mortality
c. 180-day mortality (follow-up study)

2. ICU-free days at day 28
a. Hospital LOS
b. Mechanical ventilation free days at day 28
c. Renal replacement therapy-free days at day 28
d. Vasopressor-free days at day 28

3. Endotracheal intubation. We will document time to intubation, reasons for intubation as per the treating team (neurologic deterioration that is not attributed to sedation, persistent or worsening respiratory failure of NIV such as oxygen saturation $<88 \%$, respiratory rate $>36 / \mathrm{min}, \mathrm{PaO}_{2} / \mathrm{FiO}_{2}$ ratio $<100$ or persistent requirement of $\mathrm{FiO} 2$ $\geq 70 \%$, intolerance of mask or helmet NIV, airway bleeding, copious respiratory secretions, respiratory acidosis with $\mathrm{pH}<7.25$, hemodynamic instability, significant radiological worsening). We will document mechanical ventilation parameters in the first 24 hours of intubation (peak airway pressure, plateau pressure, positive endexpiratory pressure (PEEP) $\left(\mathrm{cmH}_{2} \mathrm{O}\right), \mathrm{FiO}_{2}(\%)$, tidal volume, and respiratory rate. We will also document oxygen rescue therapies during invasive mechanical ventilation (neuromuscular blocker infusion, recruitment maneuvers, inhaled nitric oxide, prone positioning, extracorporeal membrane oxygenation (ECMO)). We will report the percentage of patients who underwent tracheostomy. 
medRxiv preprint doi: https://doi.org/10.1101/2021.07.26.21260421; this version posted July 30, 2021. The copyright holder for this preprint

(which was not certified by peer review) is the author/funder, who has granted medRxiv a license to display the preprint in perpetuity.

All rights reserved. No reuse allowed without permission.

4. Safety outcomes

a. Skin injury at the nose, face, neck, and axillae, with the highest stage during the intervention period. We will sue the stages as per the National Pressure Ulcer Advisory Panel(14): stage I: non-blanchable erythema, stage II: partial thickness, stage III: full-thickness skin loss, stage IV: full-thickness tissue loss.

b. Barotrauma, including pneumothorax, mediastinal air, subcutaneous emphysema.

c. Cardiovascular events.

d. Device complications (such as helmet deflation or malfunction).

e. Serious adverse events (SAEs).

\section{Statistical analysis}

Categorical variables will be reported as numbers and frequencies and will be compared between the study groups using the Chi-square test. Continuous variables will be reported as mean and standard deviation or median and the first and third quartiles (Q1-Q3) and be compared between the study groups using the Student's t-test or the Wilcoxon-MannWhitney test, as judged appropriate by normality testing. For serial measurements, we will test the change over time and the difference between the two study groups over time using a repeated-measures analysis of variance, with no imputation for missing values. For serial measurements, we will use Bonferroni correction to account for multiple comparisons. We will report associations as risk ratios $(\mathrm{RR})$ or hazard ratios $(\mathrm{HR})$ with $95 \%$ confidence intervals $(\mathrm{Cl})$. Tests will be two-sided and at the $5 \%$ significance level. All statistical analyses will be conducted using the SAS software version 9.4 (SAS Institute, Cary, NC, USA). The statistical analysis remains blinded to the research team until completion of primary outcome data on the study population and will be performed by the study biostatistician. A summary of the analysis plan is provided in Table 1. 
medRxiv preprint doi: https://doi.org/10.1101/2021.07.26.21260421; this version posted July 30, 2021. The copyright holder for this preprint (which was not certified by peer review) is the author/funder, who has granted medRxiv a license to display the preprint in perpetuity.

All rights reserved. No reuse allowed without permission.

\section{A. Analysis of Primary outcome}

The primary outcome will be compared in the intention-to-treat and per-protocol cohorts (effectiveness analysis) using a Chi-square test. Results will be reported as RR with $95 \% \mathrm{Cl}$. If there is a significant difference, we will report relative risk reduction (RRR), absolute risk reduction (ARR) or increase, and number needed to treat (or harm). The unadjusted coxproportional hazard model will be used as a secondary analysis tool. Kaplan-Meier curves will be generated for the alternative treatment groups and a log-rank test will be used to compare distributions. Although imbalances in baseline characteristics are unlikely with the large sample size, we will conduct an adjusted logistic regression model to adjust for the following factors (defined a priori): enrolment center and respiratory support at baseline (mask NIV support versus others).

\section{B. Analysis of secondary outcomes}

Secondary outcomes will be compared in the intention-to-treat cohort only using a Chisquare test. Results will be reported using $\mathrm{RR}$ and $95 \% \mathrm{Cl}$.

\section{Subgroup analyses}

The primary outcome will be compared in the intention-to-treat cohort only, in the following a priori defined subgroups using a Chi-square test.

1. Patients with moderate ARDS $\left(\mathrm{PaO}_{2} / \mathrm{FIO}_{2}\right.$ ratio 101-200) and patients with severe ARDS $\left(\mathrm{PaO}_{2} / \mathrm{FIO}_{2}\right.$ ratio $\left.<100\right)$

2. Obese patients (body mass index $>30 \mathrm{~kg} / \mathrm{m}^{2}$ ) and patients with a body mass index of $\leq 30$

3. Patients aged $>65$ years and $\leq 65$ years

4. APACHE II score higher or lower than the median of enrolled patients

5. Patients who were at the time of enrollment on mask NIV versus others 
medRxiv preprint doi: https://doi.org/10.1101/2021.07.26.21260421; this version posted July 30, 2021. The copyright holder for this preprint (which was not certified by peer review) is the author/funder, who has granted medRxiv a license to display the preprint in perpetuity.

All rights reserved. No reuse allowed without permission.

Results will be reported using $\mathrm{RR}$ and $95 \% \mathrm{Cl}$. We will report the results of the test of interactions for these subgroups (Supplement Table S5 online).

\section{Sensitivity analyses}

If patients with suspected COVID-19 who tested negative constituted more than $5 \%$ of the study population, we will carry a sensitivity analysis excluding these patients.

\section{E. 180-day follow up}

In a follow-up report, we will compare 180-day mortality and the EuroQol (EQ-5D-5L)(15) at 6 months scores after randomization between the two study groups.

\section{F. Interim analyses}

The interim test statistics will be conducted for the primary outcome. We will perform two formal interim analyses when $33 \%$ and $67 \%$ of the sample size has been reached. The trial may be stopped for safety $(p<0.01)$ or effectiveness $(p<0.001)$ but there will be no plans to terminate the trial for futility. We will account for alpha spending by the O'Brien-Fleming method and the final p-value will be considered at 0.048.(16)

We will also report protocol violations (Supplement Table S6).

\section{Discussion}

Several studies have investigated helmet NIV as a treatment for acute hypoxic respiratory failure.(2-6) A systematic review of RCTs and observational studies found that helmet NIV was associated with lower hospital mortality (odds ratio, $0.43 ; 95 \% \mathrm{Cl}, 0.26-0.69$ ), intubation rate (odds ratio, $0.32 ; 95 \% \mathrm{Cl}, 0.21-0.47$ ), and complications (odds ratio, $0.6 ; 95 \% \mathrm{Cl}, 0.4-$ 0.92) compared with controls.(17) A meta-analysis of four RCTs (377 patients) showed that helmet NIV significantly increased the $\mathrm{PaO}_{2} / \mathrm{FiO}_{2}(+73.4 ; 95 \% \mathrm{Cl}, 43.9-102.9)$ and decreased the arterial carbon dioxide levels, intubation rate (relative risk, $0.21 ; 95 \% \mathrm{Cl}, 0.11$ 0.40 ) and in-hospital mortality rate (relative risk, $0.22 ; 95 \% \mathrm{Cl}, 0.09-0.50)$ compared to 
medRxiv preprint doi: https://doi.org/10.1101/2021.07.26.21260421; this version posted July 30, 2021. The copyright holder for this preprint

(which was not certified by peer review) is the author/funder, who has granted medRxiv a license to display the preprint in perpetuity.

All rights reserved. No reuse allowed without permission.

standard oxygen therapy.(18) A network meta-analysis of 25 studies that included 3804 patients with acute hypoxemic respiratory failure for reasons other than COVID-19 found significantly lower intubation risks with helmet NIV compared with standard oxygen therapy.(7) The advantages of helmet NIV over other oxygen support modalities are thought to be more prominent in patients with COVID-19. This led to the design and conduct of multiple RCTs. $(8,19)$ Recently, one trial $(n=110)$ showed no difference in the number of days free of respiratory support at 28 days (primary outcome) between helmet NIV and highflow nasal oxygen.(8)

As the efficacy of helmet NIV to improve outcomes in severe acute hypoxemic respiratory failure due to COVID-19 pneumonia has not been established, the aim of the Helmet COVID trial is to compare the effectiveness of helmet NIV compared to usual care on 28 day mortality in patients with acute hypoxic respiratory failure from COVID-19. The first patient was enrolled in February 8, 2021. As of May 6, 2021, 108 patients have been enrolled from 4 centers in Saudi Arabia.

\section{Conclusion}

The Helmet-COVID trial evaluates whether helmet NIV improves the outcomes of critically ill patients with acute hypoxemic respiratory failure due to COVID-19. It is expected to provide evidence that will inform practice regarding the use of helmet NIV for respiratory support in these patients and contribute to future clinical practice guidelines. 
medRxiv preprint doi: https://doi.org/10.1101/2021.07.26.21260421; this version posted July 30, 2021. The copyright holder for this preprint (which was not certified by peer review) is the author/funder, who has granted medRxiv a license to display the preprint in perpetuity.

All rights reserved. No reuse allowed without permission.

\section{List of abbreviations}

$\begin{array}{ll}\text { Abbreviation } & \text { Term } \\ \text { CI } & \text { Confidence Interval } \\ \text { HR } & \text { Hazard Ratio } \\ \text { ICU } & \text { Intensive Care Unit } \\ \text { IQR } & \text { Interquartile Range } \\ \text { LOS } & \text { Length of stay } \\ \text { RT-PCR } & \text { Reverse Transcription-Polymerase Chain Reaction } \\ \text { RCT } & \text { Randomized Controlled Trial } \\ \text { RR } & \text { Relative Risk } \\ \text { RRR } & \text { Relative Risk Reduction } \\ \text { SAP } & \text { Statistical Analysis Plan }\end{array}$




\section{Authors' contributions}

All authors agree to be accountable for all aspects of the work in ensuring that questions related to the accuracy or integrity of any part of the article are appropriately investigated and resolved

\section{Acknowledgments}

The authors would like to thank all the participating patients and their families, as well as the members of the Data Safety \& Monitoring Board: Chair: Dr. Nicholas S. Hill (Professor of Medicine, Chief of Pulmonary, Critical Care and Sleep Division, Tufts Medical Center, Boston, Massachusetts, USA), DSM members: Dr. Stefano Nava (Professor of Respiratory Medicine University of Bologna, Chief of the Respiratory and Critical Care Sant' Orsola Hospital Bologna, Specialist in Respiratory Medicine and Intensive Care Medicine, University of Bologna, Italy), Dr. James Mojica (Vice Chief and Clinical Director of Pulmonary \& Critical Care, Director, The Sleep Center at Spaulding, Massachusetts General Hospital, USA) and Dr. Michael Harhay (Assistant Professor of Epidemiology and Medicine-Pulmonary and Critical Care, Department of Biostatistics, Epidemiology and Informatics, University of Pennsylvania USA).

Funding The study is funded by King Abdullah International Medical Research Center (RC $20 / 306 / R)$. The study sponsor does not have any role in the study design, collection, management, analysis, and interpretation of data as well as the writing of the report.

Competing interests None declared 
medRxiv preprint doi: https://doi.org/10.1101/2021.07.26.21260421; this version posted July 30, 2021. The copyright holder for this preprint (which was not certified by peer review) is the author/funder, who has granted medRxiv a license to display the preprint in perpetuity.

All rights reserved. No reuse allowed without permission.

Figure 1: CONSORT Flow Diagram 
medRxiv preprint doi: https://doi.org/10.1101/2021.07.26.21260421; this version posted July 30, 2021. The copyright holder for this preprint

(which was not certified by peer review) is the author/funder, who has granted medRxiv a license to display the preprint in perpetuity.

All rights reserved. No reuse allowed without permission.

\section{References}

1. Amirfarzan H, Cereda M, Gaulton T, et al. Use of helmet CPAP in COVID-19: a practical review. Pulmonology. 2021:S2531-0437 (21) 00040-4.

2. Brambilla AM, Aliberti S, Prina E, et al. Helmet CPAP vs. oxygen therapy in severe hypoxemic respiratory failure due to pneumonia. Intensive Care Med. 2014;40(7):942-9.

3. Cosentini R, Brambilla AM, Aliberti $S$, et al. Helmet continuous positive airway pressure vs oxygen therapy to improve oxygenation in community-acquired pneumonia: a randomized, controlled trial. Chest. 2010;138(1):114-20.

4. Patel BK, Wolfe KS, Pohlman AS, et al. Effect of Noninvasive Ventilation Delivered by Helmet vs Face Mask on the Rate of Endotracheal Intubation in Patients With Acute Respiratory Distress Syndrome: A Randomized Clinical Trial. JAMA. 2016;315(22):2435.

5. Foti G, Sangalli F, Berra L, et al. Is helmet CPAP first line pre-hospital treatment of presumed severe acute pulmonary edema? Intensive care medicine. 2009;35(4):656.

6. Squadrone V, Coha M, Cerutti E, et al. Continuous positive airway pressure for treatment of postoperative hypoxemia: a randomized controlled trial. Jama. 2005;293(5):589.

7. Ferreyro BL, Angriman F, Munshi L, et al. Association of noninvasive oxygenation strategies with all-cause mortality in adults with acute hypoxemic respiratory failure: a systematic review and meta-analysis. Jama. 2020;324(1):57-67.

8. Grieco DL, Menga LS, Cesarano M, et al. Effect of helmet noninvasive ventilation vs high-flow nasal oxygen on days free of respiratory support in patients with COVID-19 and moderate to severe hypoxemic respiratory failure: the HENIVOT randomized clinical trial. JAMA.

9. Arabi YM, Tlayjeh H, Aldekhyl S, Al-Dorzi H, Abdukahil SA, Al Harbi MK, Al Haji H et al, Helmet noninvasive ventilation for COVID-19 patients "Helmet-COVID": study protocol for a multicenter randomized controlled trial Under review.

10. Kahan $\mathrm{BC}$, Harhay MO. Many multicenter trials had few events per center, requiring analysis via random-effects models or GEEs. Journal of clinical epidemiology. 2015;68(12):1504-11.

11. Alexiou VG, lerodiakonou V, Dimopoulos G, Falagas ME. Impact of patient position on the incidence of ventilator-associated pneumonia: a meta-analysis of randomized controlled trials. Journal of critical care. 2009;24(4):515-22.

12. Moher D, Hopewell S, Schulz KF, et al. CONSORT 2010 explanation and elaboration: updated guidelines for reporting parallel group randomised trials. BMJ. 2010;340:c869.

13. Schulz KF, Altman DG, Moher D, Group C. CONSORT 2010 statement: updated guidelines for reporting parallel group randomised trials. BMJ. 2010;340:c332.

14. Edsberg LE, Black JM, Goldberg M, et al. Revised national pressure ulcer advisory panel pressure injury staging system: revised pressure injury staging system. Journal of Wound, Ostomy, and Continence Nursing. 2016;43(6):585.

15. Herdman M, Gudex C, Lloyd A, et al. Development and preliminary testing of the new fivelevel version of EQ-5D (EQ-5D-5L). Quality of life research. 2011;20(10):1727-36.

16. O'Brien PC, Fleming TR. A multiple testing procedure for clinical trials. Biometrics. 1979:549-

56.

17. Liu Q, Gao Y, Chen R, Cheng Z. Noninvasive ventilation with helmet versus control strategy in patients with acute respiratory failure: a systematic review and meta-analysis of controlled studies.

Critical Care. 2016;20(1).

18. Luo Y, Luo Y, Li Y, et al. Helmet CPAP versus Oxygen Therapy in Hypoxemic Acute Respiratory Failure: A Meta-Analysis of Randomized Controlled Trials. 2016.

19. Tverring J, Åkesson A, Nielsen N. Helmet continuous positive airway pressure versus highflow nasal cannula in COVID-19: a pragmatic randomised clinical trial (COVID HELMET). Trials.

2020;21(1):1-10. 
medRxiv preprint doi: https://doi.org/10.1101/2021.07.26.21260421; this version posted July 30, 2021. The copyright holder for this preprint (which was not certified by peer review) is the author/funder, who has granted medRxiv a license to display the preprint in perpetuity.

All rights reserved. No reuse allowed without permission. 
Figure 1: CONSORT Flow Diagram

medRxiv preprint doi: https://doi.org/10.1101/2021.07.26.21260421; this version posted July 30, 2021. The copyright holder for this preprint (which was not certified by peer review) is the author/funder. who has granted medRxiv a license to display the preprint in perpetuity.

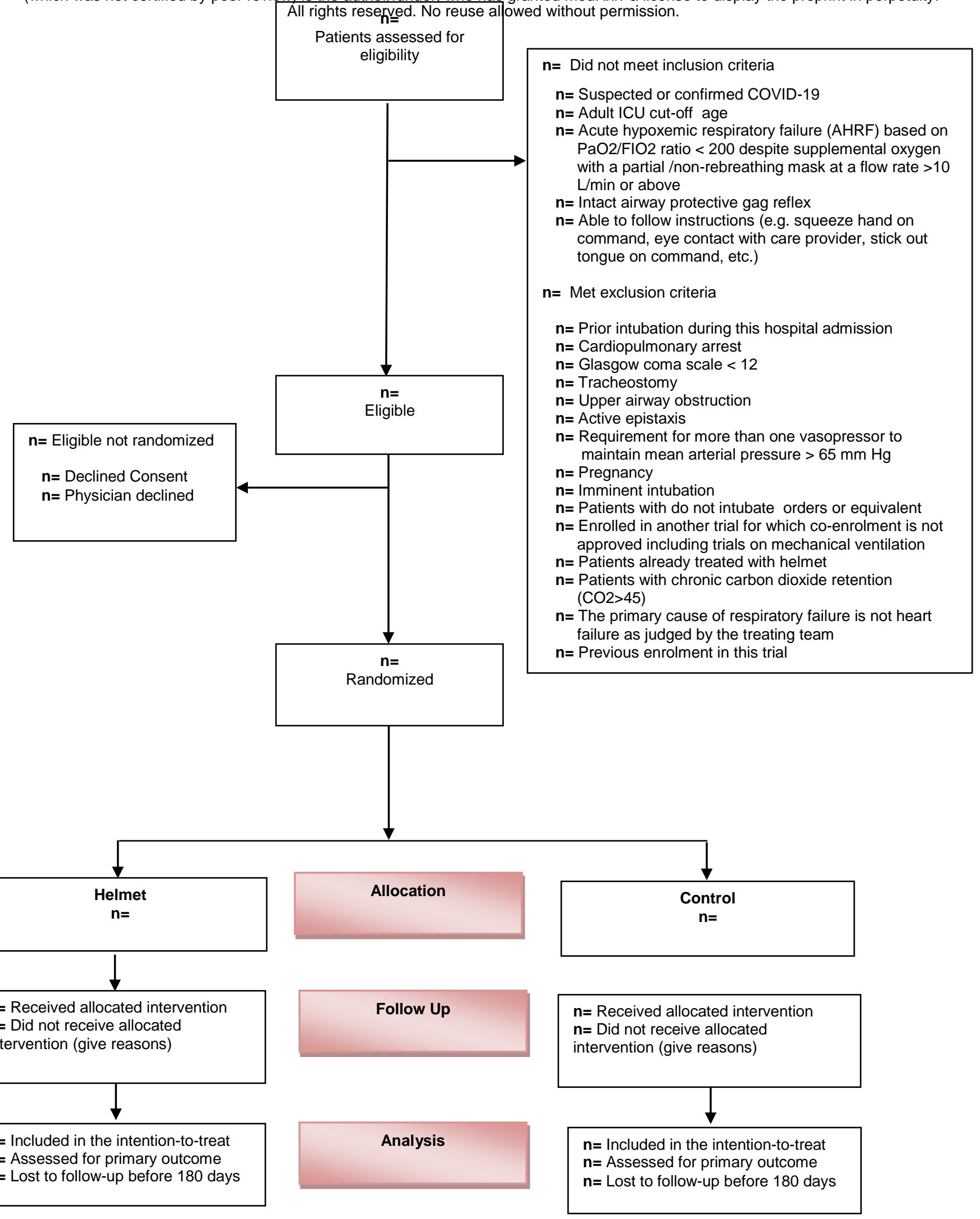



(which was not certified by peer review) is the author/funder, who has granted medRxiv a license to display the preprint in perpetuity.

Table 1: Summary of the analy ights reserved. No reuse allowed without permission.

\begin{tabular}{|c|c|c|}
\hline Variables & Intention-to-treat cohort & Per Protocol cohort \\
\hline $\begin{array}{l}\text { Baseline } \\
\text { characteristics }\end{array}$ & No statistical comparisons & None \\
\hline $\begin{array}{l}\text { Intervention and co- } \\
\text { interventions }\end{array}$ & $\begin{array}{l}\text { Chi-square, Fisher exact test, Mann } \\
\text { Whitney U test, t-test as applicable. }\end{array}$ & None \\
\hline Primary outcome & $\begin{array}{l}\text { 1. Primary analysis: Chi- } \\
\text { square. Report relative risk. } \\
\text { If a significant difference is } \\
\text { detected: relative risk } \\
\text { reduction, absolute risk } \\
\text { reduction, and number } \\
\text { needed to treat (or harm). } \\
\text { 2. Secondary analyses: } \\
\text { Unadjusted Cox proportional } \\
\text { analysis, KM curves, } \\
\text { adjusted Cox proportional } \\
\text { analysis }\end{array}$ & $\begin{array}{l}\text { 1. Primary analysis: Chi- } \\
\text { square and Relative risk. If } \\
\text { a significant difference is } \\
\text { detected: relative risk } \\
\text { reduction, absolute risk } \\
\text { reduction, and number } \\
\text { needed to treat (or harm). } \\
\text { 2. Secondary analyses: } \\
\text { Unadjusted Cox } \\
\text { proportional analysis, KM } \\
\text { curves, adjusted Cox } \\
\text { proportional analysis }\end{array}$ \\
\hline Secondary outcomes & Chi-square. Report relative risk. & Chi-square. Report relative risk. \\
\hline Safety Outcomes & $\begin{array}{l}\text { Chi-square. Report relative risk. For } \\
\text { serial measures, repeated- } \\
\text { measures analysis of variance. }\end{array}$ & $\begin{array}{l}\text { Chi-square. Report relative risk. } \\
\text { For serial measures, repeated- } \\
\text { measures analysis of variance. }\end{array}$ \\
\hline Subgroup analyses & $\begin{array}{l}\text { Chi-square. Report relative risk. } \\
\text { Tests of interaction. }\end{array}$ & None \\
\hline 180-day follow up & $\begin{array}{l}\text { Chi-square for } 180 \text {-day mortality. } \\
\text { Report relative risk. } \\
\text { Cochran-Armitage trend test for } \\
\text { EQ-5D-5L. }\end{array}$ & None \\
\hline
\end{tabular}

